\title{
RELASI DAN PERAN AKTOR DALAM PEMANFAATAN RPTRA KELURAHAN PEJAGALAN JAKARTA UTARA
}

\author{
Sugeng Wahjudi \\ IImu Komunikasi, Universitas Bunda Mulia \\ Disetujui 7 Maret 2018
}

\begin{abstract}
The development and optimization of RPTRA function as public space in Kelurahan Pejagalan generates clicks of communication nodes that make the utilization or maintenance of RPTRA complex and complicated. This research tries to reveal how role and relation of the actors in RPTRA management. The method used is the analysis of communication network patterns by making the matrix of communication relations between actors observed from the results of questionnaires and interview questions, sociometric analysis done by descriptive approach. These communication network data were analyzed with UCINET $V I$. The result of the research with the sociogram analysis showed that the average of individuals in the group had good connectivity with each other. Opinion leaders are still dominated by the formal leaders of Lurah and Ibu Lurah as well as RPTRA coordinator appointed and responsible to the lurah.

Keywords: clicks, actor relation, sociometry, opinion leader
\end{abstract}

\begin{abstract}
ABSTRAK
Pengembangan dan optimalisasi fungsi RPTRA sebagai ruang publik di Kelurahan Pejagalan menghasilkan klik simpul-simpul komunikasi yang membuat pemanfaatan atau pemeliharaan RPTRA menjadi kompleks dan rumit. Penelitian ini berusaha mengungkapkan bagaimana peran dan relasi para aktor dalam pengelolaan RPTRA. Metode yang digunakan adalah analisis pola jaringan komunikasi dengan cara membuat matriks hubungan komunikasi antar aktor yang diamati dari hasil pertanyaan kuesioner dan interview, analisis sosiometri dilakukan dengan pendekatan deskriptif. Data jaringan komunikasi ini dianalisis dengan UCINET VI. Hasil penelitian dengan analisis sosiogram menunjukan rerata individu dalam kelompok memiliki keterhubungan yang baik satu sama laiin. Opinion leader masih didominasi oleh pimpinan formal yaitu Lurah dan Ibu Lurah serta koordinator RPTRA diangkat dan bertanggung jawab terhadap lurah.
\end{abstract}

Kata Kunci: klik, relasi aktor, sosiometri, opinion leader

\section{PENDAHULUAN}

\section{Latar Belakang}

RPTRA atau Ruang Publik Terpadu Ramah Anak adalah tempat dan/atau ruang terbuka yang memadukan kegiatan dan aktivitas warga dengan mengimplementasikan $10 \quad$ (sepuluh) Program Pokok Pemberdayaan dan Kesejahteraan Keluarga untuk

*Korespondensi Penulis:

E-mail: swahjudi@bundamulia.ac.id mengintegrasikan dengan program Kota Layak Anak (PERGUB DKI No. 196 tahun 2015). RPTRA adalah wujud komitmen Pemerintah Provinsi DKI Jakarta untuk menjamin terpenuhinya hak-hak anak sehingga anak dapat hidup, tumbuh, berkembang, dan berpartisipasi secara optimal sesuai dengan harkat dan martabat kemanusiaan serta mendapat perlindungan dari kekerasan dan diskriminasi.

Pembangunan Ruang Publik Terpadu Ramah Anak di Jakarta Utara akan diutamakan di sembilan kelurahan yang 
belum memiliki RPTRA. Menurut Kepala Suku Dinas Pemberdayaan Perlindungan Anak dan Pengendalian Penduduk (PPAPP) Jakarta Utara, Hendry Novrizal sebagaimana dilansir oleh Warta Publik di Jakarta Utara khususnya, sudah ada 42 RPTRA. 10 RPTRA diantaranya dibangun dengan menggunakan APBD sedangkan sisanya dibangun dengan biaya dari CSR dan swadaya masyarakat. Pada Tahun 2017 pembangunan RPTRA tersebut difokuskan di 9 kelurahan di Jakarta Utara yang belum mempunyai RPTRA.

Pembangunan RPTRA sebagai ruang publik tidak selalu mulus. Persoalan muncul dari internal masyarakat mengingat program ini berkaitan dengan pemanfaatan lahan. Seringkali sebagian masyarakat ditempat pembangunan RPTRA merasa perubahan lahan ini mengganggu aktivitas ekonomi mereka. Sebut saja RPTRA Kalijodo yang mengubah lahan "prostitusi" yang bernilai ekonomis bagi sebagian "oknum" menjadi lahan terbuka. Demikian juga dengan RPTRA Pejagalan, perubahan lahan yang sebelumnya menjadi lahan kosong dan tempat PKL dan area perparkiran yang mendatangkan keuntungan bagi sebagian warga secara ekonomis menuntut kompensasi ganti rugi.

Ruang publik RPTRA Kelurahan Pejagalan terletak di kawasan RW. 016 Kelurahan Pejagalan Kecamatan Penjaringan Kotamadya Jakarta Utara. RPTRA ini terletak didekat kolong tol Jembatan Tiga - pintu masuk tol Jembatan Tiga. Secara geografis, lokasi RPTRA ini terletak diantara kawasan RW 016 dan RW 018 Kelurahan Pejagalan. Salah satu pihak yang terlibat dalam studi awal pembangunan RPTRA di Kelurahan Pejagalan adalah institusi pendidikan, yaitu Universitas Bunda Mulia. Fungsi kampus dalam pembangunan RPTRA adalah melakukan pemetaan sosial, survey, rembuk warga untuk menggali masukkan warga terhadap desain RPTRA, penentuan kegiatan yang akan dilaksanakan di RPTRA, serta pengelolaan dan pemeliharaan RPTRA. Secara rinci peran dari kampus (Universitas) dalam pembangunan RPTRA adalah :

Tahap I: Melakukan pemetaan sosial, sosialisasi tentang RPTRA, survey, dan rembuk warga dengan tujuan utama untuk (i) mengidentifikasi kegiatankegiatan yang selama ini dilakukan oleh warga, (ii) menggali informasi dan masukkan dari warga tentang kebutuhan, keinginan dan harapan warga terhadap RPTRA yang akan dibangun. Masukkan dan informasi yang diperoleh digunakan untuk menjadi masukkan terhadap disain RPTRA. Output dari kegiatan tahap I ini adalah disain final RPTRA yang disepakati dan diketahui oleh pemangku kepentingan RPTRA Pejagalan, yang dituangkan dalam berita acara rembuk warga finalisasi disain fisik RPTRA.

Tahap II: Melakukan rembuk warga yang bertujuan untuk memfasilitasi pemilihan calon pengelola RPTRA, memfasilitasi kegiatankegiatan yang akan dilaksanakan di RPTRA, dan memfasilitasi pembuatan jadwal kegiatan RPTRA. Output dari kegiatan tahap II ini adalah berita acara pengangkatan dan pengesahan pengelola RPTRA.

Tahap III: Melakukan pendampingan terhadap pengelola RPTRA selama 6 (enam) bulan, dan melakukan kunjungan pendampingan pengelolaan RPTRA minimal 6 (enam) kali selama masa 6 (enam) 
bulan pendampingan tersebut diatas. Output dari tahap III ini adalah berita acara minimal 6 (enam) kunjungan pendampingan selama periode 6 (enam) bulan pendampingan pengelolaan RPTRA oleh Universitas Bunda Mulia.

Saat ini RPTRA yang secara khusus diperuntukan pada warga RW 016 Kelurahan Pejagalan sudah berfungsi sebagai ruang publik yang dimanfaatkan oleh warga. Universitas Bunda Mulia sebagai bagian penting dalam persiapan maupun proses pendampingan sudah selesai dan selanjutnya pengelolaan RPTRA kembali dilakukan secara swadaya oleh masyarakat.

Menurut Gubernur DKI Jakarta, Basuki Tjahaja Purnama (Ahok) saat meresmikan Ruang Publik Terpadu Ramah Anak (RPTRA) Dharma Suci, di Jalan Pluit Mas Utara, Kelurahan Pejagalan, Kecamatan Penjaringan, Jakarta Utara pada Rabu 5 April 2016 Keberadaan RPTRA dimaksudkan untuk mempermudah masyarakat berinteraksi sosial sehingga diharapkan lebih peduli terhadap masalah sosial.

(Beritasatu.com, http://www.beritasatu.com/megapolitan/358 $555)$.

Persoalan penting dalam pembangunan RPTRA ini adalah pada masalah pengelolaan dan pemanfaatan ruang publik tersebut. Penelitian ini dilakukan untuk memperoleh deskripsi mengenai pemanfaatan RPTRA kelurahan pejagalan pasca proses pendampingan yang dilakukan oleh Universitas Bunda Mulia selesai.

Penelitian ini diarahkan untuk meningkatkan optimalisasi penggunaan RPTRA secara swadaya melalui identifikasi aktor lokal sebagai pengelola dan bagaimana relasi para aktor ini dengan para pengguna .

\section{Rumusan Masalah}

Peneliti melakukan penelitian dengan melakukan identifikasi dan peran aktor lokal dalam pengelolaan RPTRA dan menganalisis bagaimana relasi para aktor dengan masyarakat. Komunikasi dalam transformasi struktur sosial dan budaya pada masyarakat RPTRA Dharma Suci yang telah ditetapkan sebagai kawasan sentra industri perikanan.

\section{Urgensi Penelitian}

Penelitian ini penting dilakukan untuk memahami permasalahan dengan proses pemanfaatan RPTRA kelurahan Pejagalan secara swadaya yang dilakukan oleh pengelola lokal pasca selesainya tugas pendampingan yang dilakukan oleh mitra dari kampus Universtas Bunda Mulia.

Pengembangan dan optimalisasi fungsi RPTRA sebagai ruang publik di Kelurahan Pejagalan sebagai proses transformasi yang berlangsung di masyarakat bisa jadi tidak berjalan secara alami dan asli. Hal ini dimungkinkan jika dalam masyarakat sekitar RPTRA juga berkembang berbagai klik dan simpulsimpul yang membuat pemanfaatan atau pemeliharaan RPTRA menjadi kompleks dan rumit.

Penelitian ini berusaha mengungkapkan bagaimana peran dan relasi para aktor dalam pengelolaan RPTRA secara swadaya dalam transformasi pasca selesainya tugas pendampingan dari Universitas Bunda Mulia berkaitan dengan tata cara pengelolaan RPTRA

Penelitian ini penting dilakukan sekaligus untuk mengetahui bagaimana proses transformasi pengelolaan berjalan pada jejaring komunikasi diantara pengelola RPTRA .

\section{TINJAUAN PUSTAKA}

Manusia tidak mungkin tidak berkomunikasi (cannot not communicate). Manusia juga tidak mungkin tidak menjalin relasi dengan orang lain. Dari mulai di rumah bersama anggota keluarga, di 
kampus atau tempat kerja dengan teman, di kampung dimana kita tinggal dan sebagainya. Pada dasarnya individu adalah anggota dari suatu jaringan, terhubung dengan orang lain, baik kecil ataupun besar.

Manusia berinteraksi secara sosial merupakan anggota dari berbagai kelompok kecil. Misalnya adalah keluarga, tetapi kita juga berperan sebagai anggota tim, kelompok sepermainan (peer-group), organisasi profesi, primordial, dan seterusnya. Kelompok kecil adalah sekumpulan perorangan yang relatif kecil yang masing-masing dihubungkan oleh beberapa tujuan yang sama dan mempunyai derajat organisasi tertentu di antara mereka. Studi pada persoalan relasi dan peran aktor pada suatu tindakan komunikasi dapat dipelajari melalui analisis jaringan komunikasi. Setiap individu akan memiliki koneksi dengan individu lainnya. Relasi yang terbentuk antar individu menjadi studi komunikasi yang menarik.

Jaringan adalah rangkaian "ikatanikatan" yang menyebabkan sekumpulan titik-titik yang ada dan bisa dikategorikan atau digolongkan sebagai "satu-kesatuan" yang berbeda dengan satu-kesatuan yang lain, atau merupakan sistem dari "nodes" dan "links" (Kadhusin, 2004: 24). Sebuah jaringan terdiri atas seperangkat objek (dalam term matematika, nodes) dan sebuah pemetaan atau deskripsi hubungan antara objek dan nodes. Jaringan sederhana terdiri dari dua objek, 1 dan 2, dan satu hubungan yang menghubungkannya. Aktor (node) 1 dan 2, sebagai contoh, bisa jadi manusia, dan hubungan yang menghubungkan mereka mungkin saja berada pada ruang yang sama. Tetapi ketika terjadi lebih dari satu hubungan maka disebut multiplex relationship. Studi jaringan komunikasi pada intinya adalah mengkaji relasi, yang tertarik kepada bagaimana relasi dari setiap individu (aktor) yang ada dalam kelompok. Menurut Golbeck relasi dalam jaringan komunikasi, adalah dengan siapa individu (aktor) melakukan interaksi, siapa aktor yang paling banyak melakukan relasi dan mana aktor yang tidak pernah melakukan interaksi (Golbeck, 2013:13). Setiap individu merupakan anggota dari berbagai kelompok kecil. Misalnya adalah keluarga, setiap individu juga berperan sebagai anggota tim, kelompok sepermainan (peergroup), organisasi profesi, primordial, dan seterusnya

\section{Relasi Aktor dalam Studi Jaringan Komunikasi}

Relasi yang terbentuk antar individu menjadi studi komunikasi yang menarik khususnya mengkaji bagaimana keterhubungan antara aktor dapat membentuk peranan dan fungsi individu. Marrin dan Wellman menyatakan bahwa relasi jaringan komunikasi adalah $A$ set of socially relevant node connected by one or more relations. Node, or network members, are units that are connected by the relation whose patterns we study (Marin and Wellman, 2011:11). Pryke (2012) secara spesifik menjelaskan bagaimana aktivitas individu dalam jaringan komunikasi sebagai bentuk Representation of organisational relationships as a system of node or actors linked by precisely classified connections (Pryke, 2012:78).

Penelitian jaringan memusatkan perhatian pada relasi. Metode ini bisa dipakai untuk meneliti berbagai bentuk aktor (orang/individu, lembaga, negara dsb). Tetapi yang diteliti adalah relasi, bukan atribut dari aktor. Jaringan network secara sederhana dapat didefinisikan sebagai perangkat hubungan/relationship diantara actor-actor sosial (Kadushin, 2012: 14). Eriyanto (2013) mendiskripsikan bagian penting dari analisis jaringan komunikasi adalah aktor dan hubungan diantara aktor. Studi jaringan komunikasi menggambarkan proses, sehingga bisa menjelaskan terbentuknya fenomena atau peristiwa komunikasi. Jaringan adalah struktur sosial yang diciptakan melalui komunikasi diantara sejumlah individu dan kelompok (Monge \& Contractor 2003: 154).

Aktor adalah anggota atau bagian dari sebuah jaringan, bukan kelompok (group). Seorang aktor bisa saja anggota kelompok, tetapi ia mempunyai jaringan 
yang lebih luas dari kelompok. Ini membedakan secara tegas antara penelitian jaringan dengan penelitian atribut, seperti survei. Pada penelitian atribut, diasumsikan aktor (misalnya individu) bagian dari suatu kelompok, dimana individu dalam kelompok relatif mempunyai sikap dan perilaku yang sama. Sementara penelitian jaringan, yang dilihat bukan dari mana asal kelompok individu, tetapi jaringan apa yang dibentuk oleh individu. Mungkin saja, seorang aktor (individu) mempunyai jaringan dengan orang dari lintas kelompok yang berbeda.

Aktor (node) tidak selalu berupa individu (orang), namun juga bisa berupa lembaga, negara, institusi atau perusahaan. Sedangkan link (edge) adalah relasi antar aktor. Link dilambangkan dalam sebuah garis yang menghubungkan antara aktor yang satu dengan aktor yang lain (Eriyanto, 2013: 7). Adanya garis yang menghubungkan aktor menunjukkan ada dan tidaknya sebuah relasi. Hal ini dipertegas oleh Borgatti yang menggambarkan bahwa relasi yang terbentuk dalam jaringan komunikasi Borgatti (2009) menyebutnya sebagai $A$ set of actors or node along with a set of ties of specified type (such as friendship) that link them.

Relasi jaringan komunikasi secara sederhana bisa didefinisikan sebagai metode yang berusaha menggambarkan dan menjelaskan jaringan sosial dan struktur jaringan. Jaringan adalah seperangkat aktor yang mempunyai relasi dengan aktor lain dalam tipe relasi tertentu. Studi jaringan komunikasi menggambarkan relasi aktor (bisa orang, lembaga, perusahaan, negara dan lain-lain) satu dengan lainnya dalam struktur sosial tertentu.

\section{Analisis Jaringan Komunikasi}

Analisis jaringan komunikasi merupakan salah satu metode yang dapat digunakan dalam melihat interaksi individu di dalam kelompok yang tidak hanya berfokus pada individu maupun unit sosial itu sendiri, tetapi juga melihat kualitas hubungan diantara unit sosial tersebut.
Sebagaimana dikemukakan oleh Rogers dan Kincaid (1981: 231), bahwa analisis jaringan komunikasi merupakan metode penelitian yang digunakan untuk mengidentifikasi struktur komunikasi dalam suatu sistem, dimana data hubungan mengenai arus komunikasi dianalisis menggunakan beberapa tipe hubungan interpersonal sebagai unit analisis. Serrat dalam Schmitt (2012: 216) memaparkan bahwa jaringan tersusun atas sejumlah aktor atau node (individu atau organisasi) dan hubungan sosial atau ikatan (ties) yang menghubungkan individu yang satu dengan yang lainnya. Hubungan sosial ini dapat diidentifikasi sebagai hubungan pertemanan, keluarga dan hubungan kerja. Hal serupa dikemukakan pula oleh McLeod dan Nam-Jin (2012: 89) yang menyatakan bahwa, dalam bentuk sederhana jaringan dapat direpresentasikan sebagai peta koneksi (hubungan) antara semua anggota (node) dalam jaringan. Peta jaringan dapat menggambarkan karakteristik struktural seperti; ukuran, sentralisasi (centralization), kepadatan (density), homogenitas dan jenis norma-norma yang muncul. Istilah lainnya menggambarkan posisi dari aktor (node) individu dalam jaringan seperti; sentralitas, kedekatan (closeness) dan keterhubungan (connectedness).

Hubungan merupakan hal penting dalam sistem sosial karena sistem kehidupan sosial merupakan fungsi hubungan antar bagian yang digerakkan oleh manusia. Dengan kata lain, jaringan berisikan pesan yang dihubungkan oleh manusia.

Jaringan-jaringan komunikasi terdiri atas individu-individu yang saling dihubungkan melalui pola-pola arus informasi. Cara berbagi arus informasi yang demikian dalam kurun waktu tertentu menuntun para individu untuk saling mendekatkan atau saling menjauhkan pengertian bersama mengenai suatu realitas. Yang dimaksud "realitas" bukanlah realitas fisik itu sendiri, dimana para individu tidak mempunyai kepentingan langsung, tetapi lebih berupa informasi mengenai realitas fisik itu sendiri. Interaksi para individu 
dengan lingkungannya diantarkan oleh informasi. Banyak diantaranya bukan ditujukan pada realitas fisik melainkan pada sekelompok informasi yang lain. Saling pengertian dan persetujuan yang memadai mengenai informasi simbolik yang dihasilkan dan dibagi, merupakan prasyarat terjadinya aktivitas sosial (Rogers, 1981:63)

Dalam tataran struktur sosial, jaringan komunikasi menganalisis bagaimana suatu hubungan diadik dapat tercipta diantara dua orang yang saling bertukar informasi dan menjalin keterhubungan satu sama lain. Eriyanto menyatakan bahwa link akan membentuk relasi antar aktor dalam jaringan komunikasi. Analisis jaringan komunikasi dapat mengidentifikasikan struktur komunikasi dalam sebuah sistem dan menggambarkan relasi atau interaksi dalam sebuah struktur sosial (Eriyanto, 2013: 2).

Peluang aktor agar dapat masuk ke dalam suatu jaringan sosial dan saling berkomunikasi dengan aktor lain karena ada sumber daya yang dibutuhkan dan dicari melalui orang-orang tertentu. Seseorang menjadi anggota jaringan dalam sebuah sistem sosial memberikan peluang untuk bisa mengakses sumber daya dalam memenuhi kebutuhan dan dimanfaatkan untuk kesejahteraan hidup mereka.

Penerapan analisis jaringan komunikasi dalam menjelaskan aktivitas RPTRA karena menunjukkan bagaimana keterhubungan individu dengan individu lain dapat dijelaskan dengan tindakan.

Dalam tataran konteks sosial, analisis jaringan komunikasi berkaitan dengan perubahan lingkungan pada dimensi manusia yang mengarah pada suatu proses tindakan atau outcome dari suatu sistem sosial.

\section{Road Map Penelitian}

Penelitian ini berorientasi pada empowering bagi masyarakat dalam mengembangkan kemandirian dalam pengelolaan dan pemanfaatan sumber daya (aset) lokal yang dimiliki yang pada gilirannya memperkuat soliditas dan kohesivitas masyarakat. Selanjutnya peneliti berusaha mengembangkan dengan kajian dan penelitian lanjutan. Berikut adalah road map penelitian yang dirancang oleh peneliti:

1. Optimalisasi peran opinion leader dalam pengembangan RPTRA

2. Perubahan Struktur Sosial Budaya dan pemberdayaan masyarakat

3. Transformasi RPTRA dalam integrasi sosial

4. Rasionalitas diversifikasi RPTRA dalam pemberdayaan Ekonomi Masyarakat

5. Adopsi Inovasi pemanfaatan RPTRA yang bernilai sosial dan ekonomis

\section{Desain Penelitian}

Dalam penelitian relasi dan peran aktor dalam hubungan komunikasi dalam pemanfataan PTRA sebagai obyek pengamatan melalui pengukuran sosiogram. Analisis jaringan komunikasi diletakkan dalam level individu, dan kelompok untuk memperoleh jawaban atas pertanyaan penelitian mengenai yaitu: (1), memahami klik dan simpul-simpul komunikasi masyarakat pengguna RPTRA kelurahan pejagalan ; dan (2), karakteristik dan peran personal yang terlibat dalam penggunaan RPTRA

\section{Tujuan Penelitian}

Tujuan penelitian ini adalah untuk:

1. Untuk mengetahui bagaimana relasi pengurus RPTRA Pejagalan dalam penggunaan ruang publik tersebut

2. Untuk mengetahui bagaimana peran aktor-aktor lokal dalam pemanfaatan dan pengelolaan RPTRA pasca proses pendampingan yang dilakukan oleh Universitas Bunda Mulia

\section{Manfaat Penelitian \\ Manfaat Praktis}

Penelitian jaringan komunikasi ini dapat dijadikan dasar bagi pemerintah daerah untuk mengevaluasi program, terutama yang berhubungan pengelolaan RPTRA secara swadaya dan dapat dipergunakan oleh pemerintah daerah untuk 
mengetahui berbagai masalah dalam pelaksanaan program pengembangan kawasan ruang publik semacam RPTRA .

\section{METODOLOGI PENELITIAN}

\section{Prosedur Penelitian}

Penelitian ini didesain dalam bentuk penelitian dua tahap, yang pertama penelitian akan melakukan analisis jaringan komunikasi yang yang terjadi pada masyarakat pengguna RPTRA di Kelurahan Pejagalan. Pada tahap ini penelitian dilakukan dengan pendekatan kuantitatif. melalui metode survei. Alasan penggunaan pendekatan kuantitatif karena dengan pendekatan ini akan mampu menjelaskan dengan baik dalam menganalisis hubungan individu pengguna RPTRA.

Pada tahap kedua, penelitian dilakukan secara kualitatif dan diarahkan untuk mengetahui dan memahami relasi dan karakteristik peran individu yang terdapat dalam pengelolaan RPTRA. Pada tahap ini, penelitian menggunakan pedekatan interpretif (interpretive approach). Peneliti dalam paradigma ini mempelajari relasi struktur dan tindakan sosial bermakna (meaningful social action).

\section{Pengembangan Instrumen}

Instrumen penelitan dalam jaringan komunikasi adalah dengan mengajukan pertanyaan sosiometri, yaitu pertanyaan dari siapa seseorang mendapatkan informasi tertentu. Berdasarkan pengalaman agar jaringan dapat dibuat sosiogram-nya sebaiknya orang tersebut diminta untuk menunjuk paling sedikit tiga orang sumber informasinya. Hasil yang diperoleh berupa sosiogram yang merupakan ilustrasi hubungan "siapa berinteraksi dengan siapa" atau menggambarkan interaksi dalam suatu jaringan sosial, sangat berguna untuk menelusuri aliran informasi. Analisis jaringan komunikasi dengan menggunakan sosiogram juga dapat memperlihatkan peran-peran individu dalam berinteraksi dengan sesamanya melalui jaringan komunikasi.

\section{Teknik Analisa Data}

Melakukan analisis pola jaringan komunikasi dengan cara membuat matriks hubungan komunikasi antar aktor yang diamati dari hasil pertanyaan sosiometri. Dari sini kemudian dilakukan sosiogram yang menggambarkan aliran infomasi. Analisis sosiometri dilakukan dengan pendekatan deskriptif. Data jaringan komunikasi ini dianalisis dengan UCINET VI yaitu software yang dikembangkan oleh Borgatti, el al, (2013) yang dirancang khusus untuk analisa jaringan komunikasi. UCINET VI dipilh karena mudah digunakan dan menghasilkan estimasi optimum setelah tiga ulangan perhitungan.

\section{HASIL DAN PEMBAHASAN}

\section{Gambaran Umum Objek Penelitian}

Penelitian tentang relasi peran aktor pada Ruang Publik Terpadu Ramah Anak (RPTRA) Dharma Suci didahului dengan survei lokasi untuk mendeskripsikan bagaimana keberadaan fisik, aktivitas kegiatan serta proses manajemen pengelolaan. Jenis data yang digunakan dalam survei adalah data kuantitatif yaitu data nominal dan interval untuk memperoleh gambaran tentang sosio demografis yang meliputi usia, pendidikan, akses informasi dan aktivitas responden dalam memanfaatkan RPTRA.

Kuesioner terbuka diberikan pada kelompok penggerak PKK di tingkat RW kelurahan Pejagalan sebanyak 20 orang. Informasi yang dihasilkan digunakan untuk menggali informasi tentang jaringan komunikasi antar Pengurus PKK Tingkat RW. Analisis yang dihasilkan adalah diagram sosiogram tentang jumlah klik, bentuk sentralitas, kebersamaan (betweenness) dan keterhubungan (connectedness).

Survei pendahuluan dilakukan pada awal Mei 2017 dengan melakukan 
pendekatan pada petugas pengelola RPTRA dan observasi pada ketersediaan ruang serta aktivitas. Hasil Observasi terhadap fasilitas RPTRA di setiap lokasi tidak sama dengan menyesuaikan dan mempertimbangkan dasar bangunan, namun secara umum harus ramah anak dan mempunyai akses bagi penyandang disabilitas. Berikut fasilitas yang terdapat di RPTRA Dharma Suci

1. RUANGAN PENGELOLA

Ruangan Ini di lengkapi oleh Meja, Kursi, Komputer, Mesin Fax, Printer Telepon, Filling Kabinet dan FREE WIFI.

2. RUANGAN PERPUSTAKAAN

Ruangan ini berisi buku-buku untuk anak- anak, remaja dan dewasa

3. AULA RPTRA

Ruangan ini diperuntukkan untuk tempat melaksanakan setiap kegiatan yang memerlukan tempat luas dan lebar.

4. RUANGAN LAKTASI

Ruangan ini Ber-AC dan diperuntukkan bagi pengunjung RPTRA yang mempunyai BALITA dan agar Ibu-Ibu dapat menyusui bayi-nya dengan nyaman dan tenang.

5. RUANGAN PKK MART

Ruangan ini di peruntukkan untuk usaha-usaha yang ada disekitar RPTRA menjual dan menitipkan kepada Pengelola.

6. TOILET LAKI-LAKI DAN PEREMPUAN
7. TOILET DIFABEL

8. PANTRY

9. TANAMAN OBAT KELUARGA ( $\mathrm{T}$ O G A )

10. KOLAM GIZI

11. JOGGING TRACK

12. GAJEBO

13. AMPITEATER

Pengorganisasian RPTRA di tingkat pengurus kelurahan diangkat dan diberhentikan oleh pengurus RPTRA tingkat kota/kabupaten Administrasi DKI Jakarta. RPTRA di tingkat kelurahan dipimpin langsung oleh Lurah dan terdiri dari unsur aparat kelurahan, unsur sektoral dan masyarakat .

\section{Identitas Responden}

Untuk memberikan gambaran tentang aktivitas sumber daya manusia berikut peneliti paparkan informasi mengenai identitas responden.

- Usia Responden

Berdasarkan usia responden menunjukkan bahwa sebagian besar adalah usia produktif. Hal ini mengisyaratkan bahwa ibu-ibu penggerak PKK di Kelurahan Pejagalan memiliki produktivitas dan mobiitas yang baik dalam menggerakan aktivitas kegiatan di RPTRA Dharma Suci. Berikut hasil tabulasi frekuensi berdasarkan usia responden.

Tabel 1. Usia Responden

\begin{tabular}{cccc}
\hline No & Usia responden & N & Prosentase \\
\hline 1 & 20 s.d 30 tahun & 1 & 5 \\
2 & 31 s.d 40 tahun & 8 & 40 \\
3 & 41 s.d 50 tahun & 9 & 45 \\
4 & Di atas 50 tahun & 2 & 10 \\
& Jumlah & 20 & 100 \\
\hline
\end{tabular}

Sumber : Kuesioner Identitas Responden No 2

Berdasarkan tebel di atas diperoleh informasi bahwa mayoritas usia responden adalah antara 31 tahun hingga 40 tahun sebesar $40 \%$, dan antara 41 tahun hingga 50 tahun sebesar 45\%. Kondisi ini sekaligus menggambarkan bahwa dalam segi usia para penggerak PKK di Kelurahan Pejagalan memiliki kemampuan baik secara fisik maupun psikis dapat 
menjalankan peranan dalam menggerakan kegiatan-kegiatan ibu-ibu PKK pada khususnya dan masyarakat pada umumnya untuk mengoptimalkan fungsi RPTRA

\section{- Pendidikan}

Pendidikan merupakan faktor yang sangat penting penyerapan pengetahuan, informasi maupun teknologi yang dapat mempercepat adaptasi serta memahami perubahan. Berikut komposisi tingkat pendidikan responden.

Tabel 2. Pendidikan Responden

\begin{tabular}{cccc}
\hline No & Pendidikan & N & Prosentase \\
\hline 1 & Tamat SD & 1 & 5 \\
2 & Tamat SLTP & 8 & 40 \\
3 & Tamat SMU & 11 & 55 \\
4 & Perguruan Tinggi & 0 & 0 \\
& Jumlah & 20 & 100 \\
\hline
\end{tabular}

Sumber : Kuesioner No 3

Berdasarkan kondisi di atas dapat diintepretasikan bahwa Ibu-Ibu Penggerak PKK memiliki tingkat pendidikan yang relatif baik, yaitu 55\% atau sebesar orang menyelesaikan hingga bangku Sekolah Menengah Atas. Komposisi yang demikian sekaligus menunjukkan bahwa berdasarkan tingkat pendidikan sumber daya manusia tergolong cukup baik.

Pendidikan merupakan faktor yang sangat penting bagi pembangunan suatu daerah, tingkat pendidikan memberikan sumbangan dalam hal kualitas sumber daya manusia. Kualitas pendidikan yang rendah menyebabkan terhambatnya kemampuan dalam hal produktivitas dan kemampuan bersaing dan dapat mempengaruhi perkembangan individu.

Data mengenai tingkat pendidikan, kurang lebih memberikan gambaran yang cukup baik dengan pendidikan responden secara umum, yaitu sebesar $40 \%$ menyelesaikan pendidikannya di tingkat Sekolah Menegah Pertama, sedangkan yang menyelesaikan pendidikan setingkat Sekolah Dasar sebesar 1 orang atau 5\%. Deskripsi pendidikan Pengurus PKK Tingkat RW di atas menggambarkan pendidikan Ibu-ibu Penggerak PKK yang terlibat secara aktif pada kegiatan RPTRA relatif baik.

- Keterlibatan Dalam RPTRA

Keberadaan RPTRA yang diresmikan oleh Gubernur DKI Basuki Tjahaya Purnama setahun yang lalu pada 06 April 2017, memiliki aktivitas yang cukup dinamis dengan keterlibatan yang sangat baik. Hal ini ditunjukkan melalui tabel di bawah ini.

Tabel 3. Keterlibatan dalam RPTRA

\begin{tabular}{cccc}
\hline No & Lamanya Terlibat & N & Prosentase \\
\hline 1 & Di bawah 6 bulan & 0 & 0 \\
2 & Di atas 6 sampai 1 tahun & 4 & 20 \\
3 & Di atas 1 tahun & 16 & 80 \\
& Jumlah & 20 & 100 \\
\hline
\end{tabular}

Sumber : Kuesioner no 4 
Berdasarkan keterlibatan dalam aktivitas RPTRA, tabel 3 menunjukkan tingkat partisipasi yang sangat baik. Sejak April 2016, RPTRA semenjak didirikan semua responden aktif melakukan kegiatan dan terlibat dengan $80 \%$ menyatakan terlibat di atas 1 tahun, sedangkan sisanya $20 \%$ aktif di atas 6 bulan hingga 1 tahun. Kondisi ini mengisyaratkan bahwa seluruh ibu-ibu penggerak PKK memiliki aktivitas yang mampu menggerakan dinamika pemanfaatan RPTRA.

- Sumber Informasi Pemanfaatan

\section{RPTRA}

Informasi Kegiatan RPTRA baik dalam tataran mengikuti maupun mengadakan acara diperoleh responden melalui sumber informasi yang paling dominan adalah melalui pemimpin formal Kepala Kelurahan atau pengelola RPTRA yang ditunjuk dan di angkat oleh pihak kelurahan.

Tabel 4. Perolehan Informasi Pemanfaatan RPTRA

\begin{tabular}{llcc}
\hline No & Perolehan informasi & N & Prosentase \\
\hline 1 & Kelurahan & 10 & 47,61 \\
2 & Ketua RW & 2 & 9,52 \\
3 & Ketua RT & 1 & 4,76 \\
4 & Pengelola RPTRA & 8 & 38,09 \\
& Jumlah & 21 & 100 \\
\hline
\end{tabular}

Sumber : Kuesioner No 5

Berdasarkan tabel di atas diperoleh hasil bahwa sumber institusi kelurahan menjadi tempat referensi utama dari para responden, yaitu sebesar 47,61\% sedangkan pengelola RPTRA menjadi sumber informasi sebesar 38,09\%. Selanjutnya pihak ketua RW sebesar 9.52\% dan RT sebesar $4,76 \%$.

Terdapat 1 responden yang memberikan jawaban lebih dari satu, yaitu selain ke kelurahan juga menghubungi pengelola RPTRA Dharma Suci. Dari tabel 4, diperoleh deskripsi bahwa responden yang dalam hal ini ibu-ibu penggerak PKK memiliki antusiasme yang tinggi dalam mengikuti maupun melaksanakan aktivitas di RPTRA Dharma Suci.

\section{- Frekuensi Kegiatan RPTRA}

Tabel 5 . Frekuensi Terlibat Kegiatan RPTRA

\begin{tabular}{llcc} 
No & Frekuensi per Bulan & N & Prosentase \\
1 & 1 kali & 5 & 25 \\
2 & 2 hingga 3 kali & 11 & 55 \\
3 & 4 kali & 0 & 0 \\
4 & Di atas 4 kali & 4 & 20 \\
& Jumlah & 20 & 100 \\
\hline
\end{tabular}

Sumber : Kuesioner No 6

Tabel 5 tentang Frekuensi kegiatan RPTRA yang diikuti oleh Ibu-ibu penggerak PKK sebagai responden menunjukkan bahwa mereka terlibat secara aktif dengan intensitas yang tinggi. Hal ini ditunjukkan bahwa tidak ada satupun responden yang tidak pernah terlibat, bahkan sebesar $20 \%$ menyatakan lebih dari 4 kali dalam 1 bulan, selebihnya 55\% aktif mengikuti 
kegiatan antara 2-3 kali dalam satu bulan, sedangkan sisanya hanya $25 \%$ mengikuti kegiatan sekali dalam sebulan. Tabel di atas sekaligus mengisyaratkan bahwa kegiatan RPTRA Dharma Suci sangat dinamis dan jika dihitung rata-ratanya, setiap minggu selalu terdapat kegiatan di RPTRA.

- Kegiatan RPTRA

RPTRA merupakan pusat pembelajaran, pelatihan, pengembangan dan rujukan dari berbagai kelompok kegiatan Ruang Publik Terpadu Ramah Anak (RPTRA) sekaligus tempat dan/atau ruang terbuka yang memadukan kegiatan dan aktivitas warga dengan mengimplementasikan 10 (sepuluh) program Pokok Pemberdayaan dan Kesejahteraan Keluarga untuk mengintegrasikan dengan program Kota Layak Anak.

Fokus kegiatan RPTRA mencerminkan layanan bagi anak dan layanan masyarakat menjadi wadah community center yang berfungsi sebagai pusat interaksi dan dimanfaatkan oleh seluruh elemen masyarakat dari berbagai kelompok umur. Berdasarkan jenis kegiatan berikut yang diikuti dan diselenggarakan oleh responden

Tabel 6. Kegiatan di RPTRA

\begin{tabular}{llcc}
\hline No & \multicolumn{1}{c}{ Jenis Kegiatan } & N & Prosentase \\
\hline 1 & Diskusi / Saresehan & 7 & 13,72 \\
2 & Olahraga & 4 & 7,84 \\
3 & Ketrampilan/usaha kerajinan & 6 & 11,76 \\
4 & Penyuluhan & 10 & 19,60 \\
5 & Kesehatan & 6 & 11,76 \\
6 & Rapat/Pertemuan Rutin & 15 & 29,41 \\
7 & Usaha produktif & 3 & 5,88 \\
8 & Lain-lain & 0 & 0 \\
& Jumlah & 51 & 100 \\
\hline
\end{tabular}

Sumber : Buku Kegiatan RPTRA 2017

Berdasarkan jenis kegiatan di atas, tampak bahwa kegiatan pertemuan rutin masih mendominasi dan menempati urutan pertama yaitu sebesar $29,41 \%$, diikuti oleh kegiatan penyuluhan sebesar 19,60\%, dan diskusi atau saresehan sebesar $13,72 \%$. Dari hasil prosentase ini menjelaskan bahwa RPTRA hingga satu tahun terakhir menjadi tempat yang nyaman dan representatif untuk digunakan sebagai tempat berdiskusi dan membahas kegiatan-kegiatan. Selebihnya sebesar $19,60 \%$ responden memberikan jawaban bahwa RPTRA juga menjadi tempat yang representatif untuk menerima materi-materi dalam bentuk penyuluhan. Tabel tersebut di atas juga memberikan deskripsi yang sangat positif. RPTRA Dharma Suci menjadi tempat berkumpul untuk belajar ketrampilan yang bernilai ekonomis. Sebesar $11,76 \%$ kegiatan diarahkan untuk belajar ketrampilan yang bermanfaat secara ekonomis, bahkan sebesar $5,88 \%$ mereka melakukan usaha produktif, seperti menanam tanaman toga, bunga hias maupun tata boga.

Deskripsi di atas semakin menegaskan bahwa aktivitas RPTRA Dharma Suci memiliki aktivitas yang cukup optimal dan berfungsi sebagai tempat yang akrab dan ramah untuk anak-anak, tetapi juga tempat yang memberi kontribusi bagi aktivitas positif pada masyarakatnya. 


\section{Analisis Relasi dan Peran Aktor RPTRA Dharma Suci}

Penelitian tentang relasi analisis jaringan komunikasi dan karakteristik aktor pengelola dan pengguna RPTRA ini bertujuan untuk mengetahui bagaimana jaringan komunikasi sesama Pengurus PKK Tingkat RW di RPTRA Dharma Suci yang ditetapkan sebagai kawasan dan wadah community center bagi masyarakat kelurahan Pejagalan. Analisis jaringan komunikasi merupakan suatu instrumen untuk mengidentifikasi struktur komunikasi dalam suatu sistem sosial (Rogers \& kincaid 1981). Analisis terhadap jaringan komunikasi akan menghasilkan gambar sosiogram yang menggambarkan aktoraktor yang berinterakasi di dalam suatu sistem ataupun kelompok.

Analisis sosiometri dan jaringan komunikasi yang digunakan untuk melihat yaitu:

1. Struktur Komunikasi, yaitu analisis yang digunakan untuk melihat pola hubungan dan peran individu tampak seperti banyaknya klik dan analisis peranan individu dalam jaringan komunikasi. Klik merupakan sebuah subsistem, dimana elemen-elemen dalam subsistem relatif lebih sering berkomunikasi daripada anggota lainnya dalam sistem komunikasi (Kincaid, 1981: 169).

2. Jaringan komunikasi, yang digunakan untuk menggambarkan interaksi antara Pengurus PKK Tingkat RW di RPTRA Dharma Suci yang berkaitan dengan upaya dan memperoleh dan memberikan informasi mengenai pengelolaan kegiatan di RPTRA, Pengolahan sosiometri dapat dilihat:

a. Sentralitas Lokal, yaitu derajat yang menunjukkan seberapa baik keterhubungan individu dalam lingkungan terdekat atau kedekatan antar individu. Derajat sentralitas lokal sekaligus menunjukkan jumlah maksimal yang mampu dibuat oleh individu Pengurus PKK Tingkat RW dengan Pengurus PKK Tingkat RW yang lain dalam lingkungan terdekatnya. Hasil sentralitas lokal (local centrality) diperoleh melalui program UCINET VI dengan mengukur normalized degree centrality berdasarkan data skala rasio nilai network $>$ centrality $>$ degree.

b. Sentralitas Global, adalah derajat yang menunjukkan berapa jarak yang harus dilalui oleh individu Pengurus PKK Tingkat RW untuk menghubungi semua individu Pengurus PKK Tingkat RW di dalam sistem atau kelompok. Derajat ini sekaligus menunjukkan kemampuan individu dalam menghubungi semua individu dalam sistem. Dengan menggunakan software UCINET VI, nilai sentralitas global diperoleh melalui centrality closeness melalui network> centrality> closeness dengan skala data rasio.

c. Kebersamaan (betweenness), yaitu frekuensi seorang individu melakukan hubungan dengan satu klik di antara klik lainnya. Derajat ini menunjukkan kemampuan individu untuk menjadi perantara atau penghubung antara satu aktor dengan aktor lainnya. Untuk mengetahui kebersamaan digunakan software UCINET VI dan nilai betweenness diperoleh melalui network centrality and power $>$ betweenness.

d. Hubungan (connectedness) merupakan derajat dimana anggota sistem berhubungan dengan anggota anggota lainnya di dalam sistem. nilai connectedness diperoleh dengan membandingkan semua ikatan yang sedang terbentuk dengan kemungkinan hubungan yang terjadi. Konektivitas berguna untuk memperoleh pengertian ketergantungan dan kerentanan individu (Hanneman and Riddle, 2005). Deedness dengan 
menggunakan UCINET VI nilai connectedness melalui network>centrality and power $>$ information centrality dengan data yang diperoleh skala rasio.

Pemanfaatan RPTRA Dharma Suci membentuk jaringan komunikasi berkaitan informasi mengenai berbagai kegiatan dan pemanfaatannya bagi masyarakat. Diantara Pengurus PKK Tingkat RW di RPTRA Dharma Suci, jaringan komunikasi yang terbentuk menggambarkan pola komunikasi yang menunjukkan siapa berkomunikasi dengan siapa, serta bagaimana informasi mengenai pemanfaatan RPTRA terdistribusi diantara Pengurus PKK Tingkat RW.

Pola interaksi antara Pengurus PKK Tingkat RW sekaligus akan menggambarkan perilaku Pengurus PKK Tingkat RW dalam memberi dan menerima serta menyebarkan informasi. Analisis jaringan komunikasi akan memberikan deskripsi siapa saja yang terjangkau informasi, bagaimana informasi tersebut terdistribusi ke semua anggota sistem (individu dalam kelompok) dari struktur jaringan yang terbentuk. Melalui analisis struktur jaringan komunikasi dapat diidentifikasi bagaimana peran-peran individu dalam struktur jaringan tersebut.

Analisis jaringan komunikasi Pengurus PKK Tingkat RW di RPTRA Dharma Suci ini dapat digambarkan dalam suatu sosiogram, sentralitas, dan densitas. Sosiogram tersebut dapat menggambarkan siapa berhubungan dengan siapa, bagaimana informasi terdistribusi ke semua anggota sistem dan juga menggambarkan peran-peran yang dimainkan oleh aktor (Pengurus PKK Tingkat RW) dalam jaringan komunikasi Pengurus PKK Tingkat RW.

\section{Analisis Relasi Komunikasi Pengurus PKK Tingkat RW}

Jaringan

komunikasi

menggambarkan pola interaksi yang terbentuk antar individu dalam suatu sistem. Melalui analisis jaringan komunikasi dapat diidentifikasi struktur komunikasi yang terbentuk dan seberapa banyak individu dapat terhubung dengan individu lainnya. Analisis jaringan komunikasi pada penelitian ini dilakukan terhadap Ibu-Ibu Pengerak PKK tingkat RW. Sebelum melakukan analisis sosiometri, seluruh individu dalam kelompok diberikan kode berupa angka berkisar antara 1 sampai dengan 20, dan pengkodean terhadap pihak-pihak luar kelompok yang terlibat komunikasi.

Analisis jaringan komunikasi yang dilakukan terhadap ibu-ibu penggerak PKK Kelurahan Pejagalan kelompok tani budidaya perikanan tangkap selain bertujuan untuk mengidentifikasi struktur jaringan dan struktur komunikasi yang terbentuk, juga mengidentifikasi lebih lanjut mengenai peranan jaringan komunikasi itu sendiri baik bagi individu maupun bagi performa kelompok-kelompok ibu PKK yang tergabung dalam penggurus penggerak PKK tingkat kelurahan.

Berdasarkan hasil analisis jaringan, distribusi dan pencarian informasi tentang pemanfaatan RPTRA telah menjangkau seluruh Ibu-ibu penggerak PKK di tingkat RW. Jumlah aktor-aktor yang terlibat dalam interaksi ini terdiri dari orang yang tergabung dalam sistem dan di luar sistem.

Berdasarkan hasil analisis dengan mengunakan UCINET VI diketahui terdapat 20 aktor anggota sistem dan 2 aktor di luar sistem. Dua aktor tersebut adalah Lurah dan Ibu Lurah Kelurahan Pejagalan. Sosiogram jaringan komunikasi mengenai pemanfaatan RPTRA dapat di lihat pada gambar 1 berikut ini: 


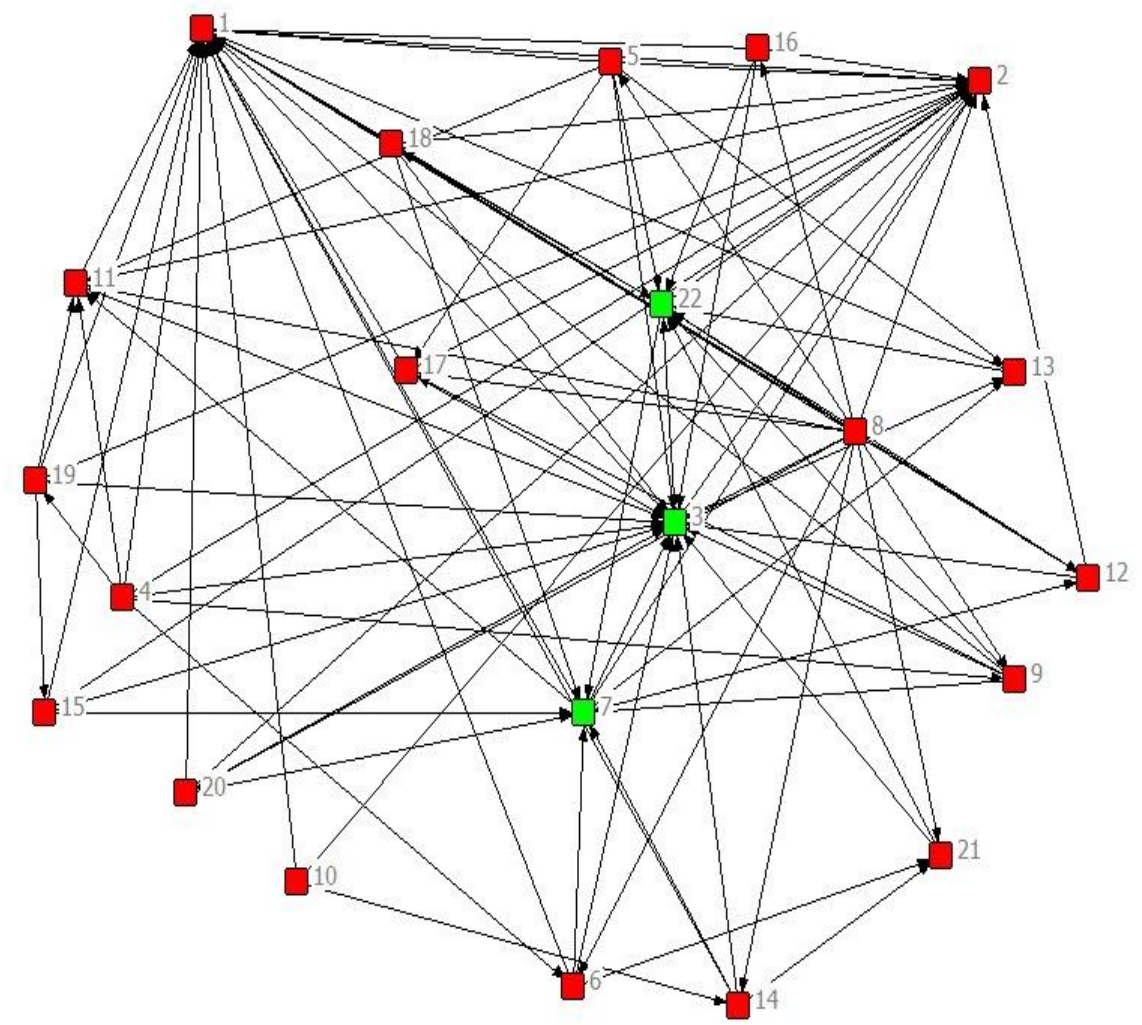

Gambar 1. Pola Jaringan Komunikasi Pemanfatan RPTRA

Sumber: Analisis Sosiometri

\begin{abstract}
Berdasarkan hasil analisis sosiogram, peneliti melihat praktek penyebaran informasi cukup merata yang ditunjukkan bahwa semua aktor dalam jaringan ini mampu menjalin komunikasi dan mengakses sumber daya informasi pada individu lain. Dari hasil analisis jaringan komunikasi ini juga menunjukkan perbedaan posisi dan peranan Ibu-ibu penggerak PKK tingkat RW dalam struktur jaringan komunikasi.
\end{abstract}

Jaringan komunikasi digambarkan pada sosiogram 1. terlihat struktur jaringan komunikasi yang bersifat personal memusat (interlocking personal network). Rogers dan Kincaid (1981) menyebutkan bahwa jaringan personal yang memusat (interlocking) mempunyai derajat integrasi yang tinggi. Dalam kondisi memusat ditandai dengan individu-individu yang homopili, dan memiliki hubungan total maksimal pada semua individu yang menjadi anggota di dalam sistem. Hasil Sosiogram menunjukan 2 individu menjadi pusat atau poros dalam informasi yaitu idno 1 dan 2, yang masing masing adalah Pak Lurah dan $\mathrm{Bu}$ Lurah. Keberadaan 2 individu ini berada di luar sistem analisis peneliti.

Sosiogram jaringan di atas merupakan jaringan komunikasi yang mampu menjangkau seluruh anggota Penggerak PKK di tingkat RW. Untuk itu mereka berbagi informasi dengan anggota lainnya maupun dengan Pak Lurah, Bu Lurah dan koordinator RPTRA Dharma Suci. Kontak yang terjadi antara aktor yang memiliki lebih dari tiga orang secara timbal balik akan menciptakan suatu hubungan yang lebih luas dan membentuk klik. 
Berdasarkan sosiogram mengenai jaringan komunikasi menggambarkan ukuran jaringan (size). Menurut Brass dalam Contractor (2003: 89), ukuran sebuah jaringan dapat diketahui dengan menghitung jumlah aktor-aktor dalam jaringan. Sosiogram dalam gambar 1 . tampak bahwa semua aktor terlibat dalam komunikasi mengenai budidaya. Dari keseluruhan 20 anggota pengurus PKK RW terdapat 17 aktor, atau aktor dapat minimal menyebut empat orang dalam berbagi informasi tentang Pemanfaatan RPTRA.

Untuk bentuk jaringan komunikasi dalam hal konteks pemanfaatan RPTRA jaringan komunikasi berbentuk $\mathrm{Y}$ dan Roda. Klik dalam bentuk Y pada jaringan komunikasi ini tampak bahwa kelompok menjadi sentralistik dengan menempatkan seseorang menjadi poros. Individu yang berada di Poros akan mengendalikan alur informasi yang tersebar diantara 2 orang lainnya yang berkomunikasi.

Dalam alur jaringan komunikasi Pemanfaatan RPTRA tampak terdapat pimpinan yang jelas ditunjukkan aktor id-3, id-7 dan id- 22. Terdapat anggota lain berperan sebagai pemimpin ke tiga aktor tersebut, yaitu id-1, dan id-2, yang dapat mengirimkan dan menerima pesan dari tiga orang lainnya.

Selain bentuk Y, sosiogram mengenai pemanfaatan RPTRA yang diperoleh melalui pertanyaan sosiometrik juga diperoleh bentuk Roda. Bentuk Roda menggambarkan bahwa sumber informasi terletak di pusat Roda, sementara anggota lainnya terdapat di sekitar jari-jari Roda. Jumlah individu yang berada dipusat jarijari memainkan peranan yang sangat penting dalam mendistribusikan dan menerima informasi. Dengan demikian dapat digambarkan, bahwa pengaturan arus informasi pada jaringan komunikasi budidaya terdapat di pusat Roda yang sekaligus menandakan peran strategis serta kekuasaan yang terpusat pada beberapa orang, yaitu aktor dengan id- 3, 7 dan 22 untuk di dalam sistem, dan id-1, dan id-2 untuk di luar sistem. sedangkan untuk anggota pengikut yang berada disekitar jarijari berpeluang kecil untuk ikut berpengaruh dalam jaringan komunikasi.

\section{Identifikasi Peran Aktor dalam Jaringan} Identifikasi terhadap sosiogram jaringan komunikasi pemanfaatan RPTRA Dharma Suci terdapat 5 klik, dimana masing-masing klik mempunyai jumlah aktor yang berbeda. Untuk mengetahui identifikasi klik dan karakteristik peranan individu (opinion leader) dalam jaringan komunikasi dapat di lihat pada tabel berikut ini:

\section{Tabel 7. Klik dan Anggota Jaringan Komunikasi}

\begin{tabular}{ccc}
\hline Klik & Aktor & Jumlah Anggota \\
\hline 1 & 1 & 19 \\
2 & 2 & 16 \\
3 & 3 & 18 \\
4 & 7 & 8 \\
5 & 22 & 9 \\
\hline
\end{tabular}

Sumber: Olah data Analisis Sosiometri

Tabel di atas menjelaskan banyaknya klik dan anggota atau aktor yang terdapat dalam klik. Dari 5 klik yang ada dan berdasarkan gambar sosiogram, masing-masing klik dapat terhubung satu 
sama lain melalui peran individu dalam jaringan.

\section{a. Opinion leader}

Identifikasi terhadap sosiogram jaringan komunikasi mengenai pemasaran, terdapat empat klik dengan karakteristik opinion leader yang berbeda-berbeda. Individu-individu yang menjadi opinion leader sebagian besar memiliki kesamaan karakteristik. Dalam analisis sosiometri opinion leader merupakan salah satu peranan yang dimiliki oleh individu yang paling populer dalam sebuah jaringan. Individu yang teridentifikasi sebagai opinion leader akan menempati posisi sentral dan menjadi pusat perhatian. Hanneman dan Ridle (2005: 187) menyatakan bahwa individu yang berperan sebagai opinion leader akan menempati posisi yang menguntungkan, karena mereka memiliki banyak hubungan, dan cara alternatif untuk memenuhi kebutuhan dan tidak terlalu bergantung pada orang lain.

Aktor yang menjadi opinion leader dalam klik adalah yang paling banyak dihubungi oleh anggota lain yang memiliki peran sebagai opinion leader adalah dalam sosiogram jaringan komunikasi ditunjukkan oleh aktor yang yang memiliki derajat konektivitas tinggi. Individu tertentu yang paling banyak terhubung dengan individu lain merupakan individu yang dapat memainkan peran sebagi opinion leader.

Sosiogram struktur jaringan komunikasi menggambarkan sumber informasi (opinion leader) adalah individu id-1, id-2, dan id-3.

Berdasarkan tabel 8 tentang klik dapat diidentifikasi terdapat 5 orang yang memiliki jumlah ikatan dalam jaringan yaitu aktor id-1, id-2, id-3, id-7, dan id22. Ketiga orang tersebut adalah individu memiliki intensitas komunikasi yang paling tinggi dibandingkan individu yang lain. Ketiga individu (id-1, id-2, dan id-3.) tersebut merupakan anggota yang paling popular.

Aktor nomor 1 dan nomor 2, adalah Lurah dan Bu Lurah, berkaitan dengan posisi sosial dan jabatannya menempatkannya menjadi tokoh masyarakat sekaligus berperan sebagai opinion leader. Opinion leader berikutnya adalah aktor nomor id-3, sebagai Pengelola atau koordinator RPTRA , mempunyai ikatan terhadap semua individu dalam jaringan komunikasi maka wajar menjadi opinion leader. Posisi opinion leader dalam jaringan komunikasi sangat dipengaruhi oleh ketokohannya di dalam jaringan komunikasi.

Individu tersebut di atas adalah individu yang populer yang berperan sebagai opinion leader dan memiliki intensitas berkomunikasi paling sering dalam kelompok tani. Aktor dengan id3 selain sebagai opinion leader dalam kliknya, juga berperan sebagai bridge yang menghubungkan dengan petani tambak dengan aktor id-7 dan id-22.

b. Bridge

Berdasarkan sosiogram jaringan komunikasi budidaya menunjukkan sumber informasi yang seringkali dirujuk adalah aktor dengan kode id-1, id-2, id-3, id-7, dan id-22. Mereka bisa disebut sebagai bridge (jembatan). Individu yang berperan sebagai bridge merupakan individu yang menghubungkan satu klik dengan klik yang lain dimana aktor tersebut juga menjadi anggota klik tersebut. Aktoraktor yang berperan sebagai bridge dalam jaringan komunikasi pemanfaatan RPTRA dapat terjadi pada masing-masing aktor yang cenderung memiliki intensitas tinggi dalam berkomunikasi dan terbuka memberi dan menerima informasi.

Peran gatekeeper yaitu individu yang mengontrol arus informasi diantara pengurus PKK di tingkat RW, dilakukan oleh aktor id-1, id-2, dan id3. Berdasarkan penghitungan connectivity dan connectedness 
menunjukkan bahwa mereka memiliki keterjangkauan dan keterhubungan yang tinggi. Selain 3 aktor tersebut terdapat juga 2 aktor yang memiliki intensitas relasi yang cukup tinggi dan memiliki keterjangkauan dan keterhubungan yang paling tinggi adalah aktor id-7 dan id-22 yang mampu memainkan peran sebagai gate keeper.

Pada umumnya individu yang menjadi opinion leader dalam jaringan komunikasi merupakan individu yang memiliki karakter yang sama yaitu tokoh masyarakat setempat. Dalam hal pendidikan aktor nomor 1 dan 2 memiliki pendidikan sarjana dan aktor nomor 3 merupakan tokoh masyarakat dan berperan sebagai koordinator RPTRA, dengan tingkat pendidikan SMU yang telah memperoleh pendidikan dan manajemen.

\section{c. Kebersamaan (Betweenness)}

Kebersamaan merupakan pengukuran sentralitas yang mengukur sejauh mana individu tertentu terletak diantara individu-individu lain dalam suatu jaringan komunikasi. Berdasarkan hasil analisis dengan menggunakan UCINET VI tingkat keterhubungan komunikasi antar petani relatif beragam tergantung konten jaringan komunikasi. Untuk konten jaringan komunikasi nilai betweenness sebesar 21, 9\%, dengan nilai maksimal 20 dan minimum 0 . Nila rata-rata betweenness sebesar 21,9\% menunjukkan tidak terlalu berpusat peran sentralitas aktor. Pengukuran pada betweenness ini sekaligus menunjukkan bahwa para aktor dalam jaringan tidak ada yang bersifat dominan atau menonjol sebagai pusat referensi atau sumber informasi. Berikut hasil olah data:

Tabel 8. Betweeness Centrality

\begin{tabular}{|c|c|c|}
\hline & Betweenness & nBetweenness \\
\hline 1 Mean & 8.864 & 2.110 \\
\hline 2 Std Dev & 20.812 & 4.955 \\
\hline 3 Sum & 195.000 & 46.429 \\
\hline 4 Variance & 433.148 & 24.555 \\
\hline 5 SSQ & 11257.662 & 638.189 \\
\hline $6 \mathrm{MCSSQ}$ & 9529.253 & 540.207 \\
\hline 7 Euc Norm & 106.102 & 25.262 \\
\hline 8 Minimum & 0.000 & 0.000 \\
\hline 9 Maximum & 97.033 & 23.103 \\
\hline $10 \mathrm{~N}$ of Obs & 22.000 & 22.000 \\
\hline \multicolumn{3}{|c|}{ Network Centralization Index $=21.99 \%$} \\
\hline
\end{tabular}

Sumber : Analisis Betweneess Data Sosiogram

Data tersebut menunjukkan bahwa tingkat kebersamaan yang dimiliki anggota Pengurus PKK Tingkat RW mayoritas tergolong cikup tinggi. Hal ini berhubungan dengan tingkat keaktifan anggota yang cukup dimana aktivitas anggotanya terhubung dalam jaringan komunikasinya sebesar 21,99 $\%$.

Betweenness mencerminkan sejauh mana aktor itu terletak di antara aktor- aktor lain dalam jaringan. Langkah ini memperhitungkan konektivitas tetangga aktor, memberikan nilai yang lebih tinggi untuk aktor yang paling banyak terhubung dengan aktor lain. Langkah ini mencerminkan jumlah orang yang menghubungkan seseorang secara tidak langsung melalui mata-rantai.

Kebersamaan merupakan pengukuran sentralitas yang mengukur sejauh mana individu tertentu terletak diantara 
individu-individu lain dalam suatu jaringan komunikasi. Menurut Freeman (1978) konsep kebersamaan mengacu pada tingkat frekuensi seorang individu yang berada di antara individu-individu yang berhubungan dalam suatu jalur komunikasi. Jika seseorang berada dalam suatu jalur komunikasi yang menghubungkan antar individu atau klik maka individu tersebut memiliki posisi yang sentral. Individu dengan nilai kebersamaan tinggi mempunyai potensi kendali komunikasi yang dapat memainkan potensi sebagai broker atau gatekeeper dalam suatu jaringan. Individu lain akan menjadi tergantung kepadanya jika jalur yang menghubungkannya dengan orang lain harus melewati individu tersebut.

\section{d. Connectedness}

Hubungan (connectedness) merupakan derajat anggota-anggota sistem berhubungan dengan anggota-anggota lain dalam jaringan komunikasi. Nilai connectedness diukur dengan membandingkan semua ikatan yang sedang terbentuk dengan kemungkinan hubungan yang mungkin terjadi. Jika ada berbagai jalur yang berbeda yang menghubungkan dua individu maka, mereka memiliki "konektivitas" yang tinggi dalam arti bahwa ada beberapa cara untuk mencapai dari satu individu ke individu yang lain. Konektivitas dapat menjadi ukuran yang berguna untuk mendapatkan pengertian tentang ketergantungan dan kerentanan individu, Hanneman and Riddle (2005: 231).

Individu yang memiliki nilai keterhubungan maksimum menunjukan bahwa individu tersebut adalah individu yang paling berpengaruh, yaitu yang paling banyak memiliki hubungan dengan individu lain dalam sistem, dan individu yang memiliki nilai minimum adalah individu yang paling sedikit memiliki hubungan dengan individu lain dalam sistem.

Tabel .9 Connectedness Jaringan Komunikasi

\begin{tabular}{|clc|}
\hline \multicolumn{1}{l}{ Id } & \multicolumn{1}{c}{ Connectedness } \\
& 1 & 5.242 \\
& 2 & 4.896 \\
& 3 & 5.234 \\
\hline & & \\
& & 1 \\
& & Inform \\
& & --------- \\
1 & Mean & 3.633 \\
2 & Std Dev & 0.833 \\
3 & Sum & \\
4 & Variance & 0.694 \\
5 & SSQ & 305.616 \\
6 & MCSSQ & 15.261 \\
7 & Euc Norm & 17.482 \\
8 & Minimum & 2.107 \\
9 & Maximum & 5.242 \\
10 & N of Obs & 22.000 \\
& & \\
\hline
\end{tabular}

Sumber: Analisis Connectedness Data Sosiogram 
Berdasarkan hasil analisis data yang disajikan pada tabel 9 diperoleh nilai keterhubungan Ibu-ibu Penggerak PKK Tingkat RW, yaitu nilai maksimum keterhubungan menunjukkan 5,242 dan nilai minimum keterhubungan 2.107 untuk topik jaringan komunikasi mengenai pemanfaatan RPTRA Dharma Suci. Tabel di atas juga menjelaskan bahwa rata-rata individu dapat membuat hubungan dengan 4 orang dalam jaringan sistem.

Dari Tabel di atas juga diperoleh deskripsi individu yang paling banyak dihubungi oleh petani tambak adalah id-1, id-2 dan id-3. Aktor id-1 yaitu adalah individu yang paling memegang peranan penting dalam jaringan komunikasi. Sebagai sentral keterhubungan bagi anggota lain, yaitu dengan id-1 ini menjadi sangat kuat karena memiliki peran dominan dalam jaringan komunikasi, hal ini terjadi karena id-1 adalah memiliki jabatan Lurah serta memiliki banyak hubungan dengan sumber informasi dari luar.

Aktor Indvidu lain yang memiliki nilai keterhubungan cukup tinggi adalah $\mathrm{Bu}$ Lurah, selain sebagai tokoh masyarkat, beliau secara formal juga otomatis menjadi Ketua Tim Penggerak Tingkat Kelurahan relatif berhasil dan menjadi rujukan bagai anggota kelompok lain. Munculnya tokoh id- 3 juga memiliki kemampuan untuk dihubungi dan menghubungi anggota yang lain. Id-3 adalah koordinator RPTRA.

\section{e. Sentralitas}

Derajat sentralitas yang terdiri dari derajat beragam individu dalam sosiogram yang dapat menunjukkan seberapa baik terhubungnya individu tertentu dengan lingkungan mereka. Pengukuran sentralisasi diperoleh melalui perbedaan angka keterpusatan pada aktor-aktor dalam jaringan yang dihitung dalam bentuk rasio pada jumlah aktual perbedaan dibagi jumlah maksimal perbedaan. Tujuan pengukuran sentralisasi dalam penelitian ini adalah untuk mengidentifikasi posisi atau lokasi serta karakteristik aktor dalam suatu jaringan komunikasi.

Sentralitas lokal dalam penelitian ini dimaksudkan sebagai individu yang secara dinamis berhubungan dengan individu lain dalam sebuah sistem. Nilai sentralitas lokal menunjukkan jumlah lingkungan yang mampu dibuat oleh individu dalam lingkungan terdekatnya. Individu yang memiliki sentralitas lokal yang besar disebut opinion leader dan individu yang memiliki sentralitas lokal yang kecil disebut pemencil (isolate). Menurut Scoot (2000: 233) sentralitas lokal dapat bersifat relatif, dan memperhatikan keunggulan relatif individu yang menjadi opinion leader dalam hubungan lingkungan terdekat. Pengukuran sentralitas akan memberikan informasi keberagaman derajat individu dalam sosiogram sekaligus menunjukkan seberapa baik terhubungnya individu dengan lingkungannya serta keterunggulan individu dalam sistem.

Secara umum sentralitas jaringan komunikasi budidaya perikanan tambak yang terbangun keseluruhan cukup kuat, dimana network centralization outdegree sebesar 51,47\% dan network centralization (in degree) sebesar $76,417 \%$. Derajat sentralitas lokal petani pada jaringan informasi budidaya selengkapnya ditunjukan pada tabel berikut: 
Tabel 10. Descriptive Statistic Sentralitas

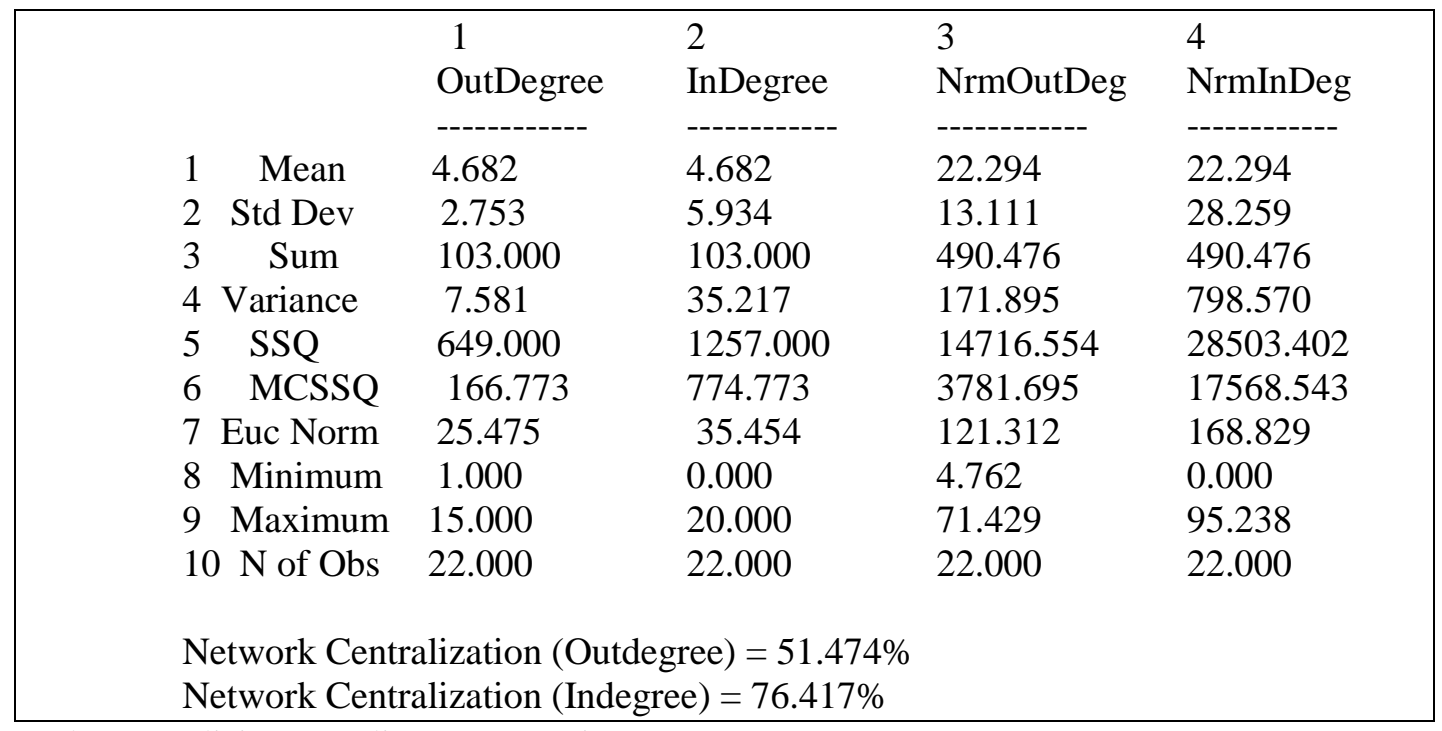

Sumber: Analisis Sentralitas Data Sosiogram

Berdasarkan tabel di atas dapat dilihat bahwa nilai sentralitas lokal anggota kelompok petani tambak dalam memperoleh informasi pemanfaatan RPTRA cukup beragam. Tabel di atas juga menunjukkan rata-rata setiap orang menghubungi 4,682 atau lima orang dalam jaringan komunikasi. Berdasarkan hasil analisis, diperoleh hasil nilai in degree centrality adalah maksimal 20 dan minimal 0 . Nilai indegree menunjukan tingkat/derajat aktor dihubungi oleh aktor lain dalam memperoleh informasi. Sedangkan out degree centrality maksimum 15 dan minimun 1. Nilai out degree menunjukkan tingkat aktor menghubungi aktor lain dalam sistem jaringan komunikasi.

Nilai indegree terbesar pada jaringan komunikasi ini adalah aktor dengan id3 dengan posisi sebagai koordinator RPTRA dan mampu menjalankan peran sebagai salah salah satu rujukan sumber informasi dalam pemanfaatan RPTRA.

\section{SIMPULAN}

Simpulan

Penelitian tentang relasi dan peran aktor dalam pemanfaatan RPTRA diperoleh simpulan sebagai berikut :

1. Rata rata sentralitas lokal adalah 4,682. Nilai sentralitas lokal ini menunjukan jumlah hubungan maksimal yang mampu dibuat individu tertentu dengan individu lain yang berada dalam lingkungan terdekatnya dalam pencarian informasi. Berdasarkan hasil analisis diketahui rerata individu memiliki keterhubungan dengan individu lain dalam pencarian informasi sebanyak 4 individu dari 21 individu dalam kelompok. Individu yang berperan dalam jaringan komunikasi sebagai sumber infomasi adalah indvidu dengan id-1, id-2, dan id-3, sementara individu yang aktif dalam mencari infomasi adalah id-8, id-4, id5, dan id-3.

2. Sentralisasi menunjukan derajat kemampuan individu untuk dapat menghubungi semua individu lain dalam sistem. Derajat sentralitas global dapat memberikan petunjuk mengenai siapa-siapa saja di dalam 
sebuah sistem yang dapat menjadi kunci penyebar informasi. Berdasarkan hasil analisis data diketahui bahwa nilai sentralitas global maksimal sebesar 273 dengan retara nilai sentralitas global sebesar 236 . Aktor-aktor yang memiliki sentralitas global tertinggi antara lain individu berturut-turut yaitu dengan id-1, id-3, dan id-2.

3. Keterhubungan (connectedness). Hubungan (connectedness) adalah derajat di mana anggota-anggota sistem berhubungan dengan anggota-anggota lain dalam sistem. Konektivitas dapat menjadi ukuran yang berguna untuk mendapatkan pengertian tentang ketergantungan dan kerentanan individu. Nilai rerata keterhubungan dalam jaringan komunikasi ini adalah sebesar 3,633 ini menunjukan rerata individu memiliki keterhubungan dengan sesama anggota dalam kelompok sebesar 3,6. Individu dengan keterhubungan maksimal sebesar 5,2 dan terendah 2,107. Ini menunjukan rata rata anggota dalam kelompok memiliki keterhubungan yang baik satu sama lain.

4. Opinion leader masih didominasi oleh pimpinan formal yaitu Lurah dan Ibu Lurah serta koordinator RPTRA diangkat dan bertanggung jawab terhadap Lurah.

5. Penelitian ini menghasilkan temuan bahwa para Pengurus PKK tingkat RW memiliki keterhubungan yang sangat baik satu sama lain, yang memungkinkan akttivitas RPTRA berjalan dengan baik.

\section{Saran}

a. Jaringan komunikasi yang terbangun dalam pemanfataan RPTRA dapat dimanfaatkan untuk pengembangan komponen kelembagaan yang ada secara sosial ekonomi. Jaringan komunikasi yang ada dapat mengatasi masalah hambatan diseminasi informasi dan sumbatan masalah komunikasi yang terjadi baik dalam pengelolaan RPTRA.

b. Lebih dari itu jaringan komunikasi dapat dikembangkan dan digunakan untuk membangun kerja sama antar kelompok RPTRA baik secara internal maupun eksternal dengan sesama kelompok RPTRA yang lain sebagai bentuk komunikasi sosial antar pengelola RPTRA.

c. Studi jaringan komunikasi menghasilkan upaya-upaya pemberdayaan yang sesuai dengan kearifan lokal. Namun demikian tetap diperlukan peranan dari pihak pemerintah terutama dalam perubahan pola pikir masyarakat, sekaligus studi jaringan komunikasi dapat dijadikan sebagai tolak ukur keberhasilan program pengembangan RPTRA.

\section{DAFTAR PUSTAKA}

Beritasatu.com, http://www.beritasatu.com/megapol itan/358555., diunduh pada hari Rabu,11 April 2017 pukul 15.32

Borgatti, Stephen P, Everett, Martin G. and Johnson, Jaffrey C. (2013). Analyzing Social Network. London: Sage Publication.

Eriyanto. (2013). Analisis Jaringan Komunikasi, Strategi Baru Dalam Penelitian Komunikasi. Jakarta: Kencana Prenada Media.

Golbeck. (2013). Analyzing the Social Web. Boston: Elservier.

Kaldushin, Charles. (2012). Understanding Social Network: Theory, Concept, and Finding, New York: Oxford University Press.

Kincaid, Rogers. (1981). Communication Network, Toward a New Paradigm for research. New York and London: Free Press. 
Marin, Alexandra, and Barry Wellman. (2011). Social network analysis: An introduction. In The SAGE Handbook of Social Network Analysis. Edited by John Scott and Peter J. Carrington, 11-25. London: SAGE.

McLeod, Nam-Jin L. (2012). Social Networks, Public Discussion and Civic Engagement: a Socialization Perspective. SAGE.

Monge, P. R., \& Contractor, N. (2003). Theories of Communication networks. Oxford: University Press.
Rogers, Kincaid DL. (1981). Communication Networks. Toward a New Paradigmfor Research. New York (US): A Division of Macmillan Publishing Co.Inc.

Schmitt E. (2012). The Importance of Social Network to Inform and Support Farmers About Adaptation Strategies Regarding Climate Change in Cote det Ivoire. [Master Thesis]. Zurich (CH): Swiss Federal Instutute of Technology Zurich. 